\title{
Trichomycterus payaya, new catfish (Siluriformes: Trichomycteridae) from headwaters of rio Itapicuru, Bahia, Brazil
}

\author{
Luisa M. Sarmento-Soares ${ }^{1}$, Angela M. Zanata ${ }^{2}$ and Ronaldo F. Martins-Pinheiro ${ }^{1}$
}

Trichomycterus payaya, new species, is described from tributaries to the upper rio Itapicuru basin, northern Bahia State, Brazil. The new species is distinguished from congeners by having the head rounded anteriorly in dorsal view and slightly depressed in lateral view, supraorbital pores s6 paired, opening laterally on the supraorbital sensory branch, not emerging from an epiphyseal branch, lateral process of the urohyal distally sharp and with pointed tip, interopercular patch of odontodes longer than deep, with 21-26 odontodes, small number of pleural ribs (5-6 ribs), and dorsal fin in a posterior position. This is the first record of a Trichomycterus from the semiarid region of northeastern Brazil.

Trichomycterus payaya, espécie nova, é descrita de tributários do alto rio Itapicuru, norte do Estado da Bahia, Brasil. A espécie nova distingue-se dos congêneres por ter cabeça arredondada anteriormente em vista dorsal e ligeiramente deprimida em vista lateral, poros supraorbitais s6 pares, abrindo-se lateralmente no ramo sensorial supraorbital, não emergindo a partir de um ramo epifiseal, processo lateral do urohial afilado distalmente e com extremidades pontiagudas, placa de odontódeos interoperculares mais longa que larga, com 21-26 odontódeos, baixo número de costelas pleurais (5-6 costelas) e nadadeira dorsal em posição posterior. Este éo primeiro registro de um Trichomycterus para o semi-árido do nordeste do Brasil.

Key words: Freshwater fish, New species, Northern Bahia, Taxonomy.

\section{Introduction}

Fishes of the freshwater family Trichomycteridae form a well corroborated monophyletic assemblage and a particularly diverse group, with more than 200 species, spread throughout South and part of Central America (de Pinna \& Wosiacki, 2003). Among the eight recognized subfamilies in Trichomycteridae, the most problematic is Trichomycterinae, an apparently non-monophyletic assemblage diagnosed basically by the lack of specializations of the other subfamilies (Baskin, 1973; de Pinna, 1989; de Pinna, 1998; de Pinna \& Wosiacki, 2003). Trichomycterus is the most specious genus within the subfamily, with more than 120 nominal species, and represents one of the most widely distributed Neotropical siluriform groups, inhabiting lowlands to the high Andes, thermal waters to cold rivers, and epigean to subterranean habitats (e.g., Fernandez \& Miranda, 2007; Trajano et al., 2009). Most species have a limited distribution and display a high level of endemism (Eigenmann, 1918; Costa, 1992; Bockmann \& Sazima, 2004). The diverse group is currently undiagnosable by synapomorphies (Wosiacki \& de Pinna, 2008a).

From rivers draining the northeastern Brazilian region, eight species of Trichomycterus are known from the headwaters of rio São Francisco (T. brasiliensis Lütken, T. concolor Costa, T. macrotrichopterus Barbosa \& Costa, T. novalimensis Barbosa \& Costa, T. reinhardti (Eigenmann), T. rubiginosus Barbosa \& Costa, T. trefauti Wosiacki, and T. variegatus Costa). Also, five species are described from river basins draining Bahia State including T. bahianus Costa, from southern Bahia, T. pradensis Sarmento-Soares \& MartinsPinheiro, from extreme southern Bahia, and T.jequitinhonhae

\footnotetext{
${ }^{1}$ Museu de Biologia Professor Mello Leitão, Laboratório de Zoologia. Av. José Ruschi, 4, Centro, 29650-000 Santa Teresa, ES, Brazil. biobahia@nossacasa.net

${ }^{2}$ Departamento de Zoologia, Instituto de Biologia, Universidade Federal da Bahia, Câmpus de Ondina. Rua Barão de Geremoabo, s/n, 40170-290 Salvador, BA, Brazil. a_zanata@yahoo.com.br
} 
Triques \& Vono, T. itacambirussu Triques \& Vono, and T. landinga Triques \& Vono from the middle rio Jequitinhonha basin. The relatively small number of Trichomycterus species described from northeastern coastal Brazilian rivers contrasts the diversity found in rivers between the rio Doce and the rio Paraíba do Sul, with twenty-three species: T. albinotatus Costa, T. alternatus (Eigenmann), T. auroguttatus Costa, T. brunoi Barbosa \& Costa, T. caipora Lima, Lazzarotto \& Costa, T. caudofasciatus Alencar \& Costa, T. claudiae Barbosa \& Costa, T. florense (Miranda Ribeiro), T. fuliginosus Barbosa \& Costa, T. giganteus Lima \& Costa, $T$. goeldii Boulenger, $T$. immaculatus (Eigenmann \& Eigenmann), T. itatiayae Miranda Ribeiro, T. longibarbatus Costa, T. mariamole Barbosa \& Costa, T. mimonha Costa, T. mirissumba Costa, T. nigroauratus Barbosa \& Costa, T. pantherinus Alencar \& Costa, T. paquequerense (Miranda Ribeiro), T. potschi Barbosa \& Costa, $T$. santaeritae (Eigenmann), and $T$. vermiculatus (Eigenmann). As for some other freshwater fishes, the trichomycterins of northeastern Brazilian rivers, particularly those of coastal rivers of Bahia State, are poorly known taxonomically and many of the specimens recently sampled may belong to undescribed species. One of those species is described herein, and represents the first report of Trichomycterus from the semiarid Brazilian region between northern Bahia and Piauí State.

\section{Material and Methods}

Straight-line measurements were taken under a stereomicroscope with a digital caliper, and recorded in tenths of a millimeter. Methodology and terminology for measurements followed Tchernavin (1944), de Pinna (1992), and Trajano \& de Pinna (1996). Standard length (SL) is expressed in $\mathrm{mm}$. In order to check the position of the dorsal fin in the species examined we used the proportional distance PDL/DFC adapted from Triques \& Vono (2004) whereby PDL is predorsal length and DFC is the distance from the dorsalfin origin to the base of the middle caudal-fin rays. Measurements of pectoral-fin filament were checked in specimens greater than $30 \mathrm{~mm}$ SL. Meristic data were obtained from alcoholic and cleared and stained (c\&s) specimens. Holotype meristics indicated by asterisk when variation occurs. Fin-rays were counted under a stereomicroscope. Dorsal- and anal-fin ray counts include the two unbranched rays, visible when back lighted, and subsequent branched rays; pectoral- and pelvic-fin rays include the first unbranched plus branched rays. Vertebral counts follow de Pinna (1992). Branchiostegal rays and rib counts were verified on c\&s specimens and upon dissection of some alcoholic specimens. Osteological examination was based on c\&s specimens according to the procedures of Taylor \& van Dyke (1985). Terminology and nomenclature for osteological data followed Arratia \& Huaquin (1995) and Arratia (2003). Morphological information about Scleronema operculatum and T. nigricans were based on digital photographic images and radiographs. Specimens examined via photographic images (I) or radiographs $(\mathrm{R})$ are indicated in Comparative material section. Morphological data for T. auroguttatus, T. brunoi, T. claudiae, T. concolor, $T$. fuliginosus, $T$. giganteus, $T$. itacarambiensis, T. landinga, T. macrotrichopterus, T. mariamole, T. mimonha, T. nigroauratus, $T$. novalimensis, $T$. potchi, $T$. rubiginosus, $T$. trefauti, and T. vermiculatus were based on literature accounts (Costa, 1992; Trajano \& de Pinna, 1996; Barbosa \& Costa, 2003, 2008, 2010; Bockmann \& Sazima, 2004; Lima \& Costa, 2004; Triques \& Vono, 2004; Wosiacki, 2005; Lima et al., 2008). Institutional abbreviations are as follows: Academy of Natural Sciences of Philadephia, Philadephia (ANSP), Natural History Museum, London (BMNH), Field Musem of Natural History, Chicago (FMNH), Museu de Biologia Professor Mello Leitão, Santa Teresa (MBML), Museu de Ciências e Tecnologia, Pontifícia Universidade Católica do Rio Grande do Sul, Porto Alegre (MCP), Muséum National d'Histoire Naturelle, Paris (MNHN), Museu Nacional, Rio de Janeiro (MNRJ), Museu de Zoologia da Universidade de São Paulo, São Paulo (MZUSP), Universidade Federal da Bahia, Salvador (UFBA), and Zoologisk Museum, Kopenhagen (ZMUC).

\section{Trichomycterus payaya, new species Figs. 1-7}

Holotype. MNRJ 36665, 37.4 mm SL, Brazil, Bahia, Miguel Calmon, riacho Olhos d'água on road BA-131, tributary to rio Itapicurumirim, rio Itapicuru drainage, between Miguel Calmon and Jacobina, 40³6'21.9”S 11²0'19.5”W, 505 m a.s.1., 12 Jun 2005, A. Zanata, P. Camelier, J. O. Birindelli, O. T. Oyakawa, M. P. Geraldes \& P. Moura.

Paratypes. ANSP 190965, 2 alc., 27.2-27.8 mm SL; MBML 2559, 1 alc., $34.0 \mathrm{~mm}$ SL; MBML 2560, $1 \mathrm{c} \& \mathrm{~s}, 30.1 \mathrm{~mm}$ SL; MNRJ 36666, 2 alc., 28.6-31.6 mm SL; MZUSP 88164, 8 alc., 25.5-35.6 mm SL; UFBA 5286, 2 alc. 29.2-31.4 mm SL and 1 c\&s, $31.1 \mathrm{~mm}$ SL, collected with the holotype. UFBA 5284, 1 alc., $36.5 \mathrm{~mm} \mathrm{SL}$ and $1 \mathrm{c} \& \mathrm{~s}, 24.1 \mathrm{~mm}$ SL, Brazil, Bahia, Jacobina, stream between BR-342 and Itaitu, tributary of rio Itapicuru-mirim, rio Itapicuru drainage, 40²8'11.2”S 11¹9'41.1'W, 547 masl, 13 Jun 2005, A. Zanata, P. Camelier, J. O. Birindelli, O. T. Oyakawa, M. P. Geraldes and P. Moura.

Diagnosis. Trichomycterus payaya is distinguished from all congeners by a unique combination of features: head rounded anteriorly in dorsal view and slightly depressed in lateral view; supraorbital pores s6 paired, opening laterally on supraorbital sensory branch, not emerging from an epiphyseal branch; lateral process of urohyal distally sharp, with pointed tip; reduced number of pleural ribs (5-6 ribs); and interopercular patch of odontodes longer than deep, with 21-26 odontodes. Trichomycterus payaya can be further distinguished from all congeners inhabiting the Brazilian coastal rivers located north of rio Paraíba do Sul (T. alternatus, T. bahianus, T. brunoi, T. caudofasciatus, T. itacambirussu, $T$. jequitinhonhae, T. landinga, $T$. longibarbatus, $T$. pantherinus, $T$. pradensis) by having the dorsal fin positioned somewhat posteriorly, the distance from the dorsal-fin origin to the base of the middle caudal-fin rays 1.9-2.2 in predorsal distance (vs. 1.4-1.8 in predorsal distance). 


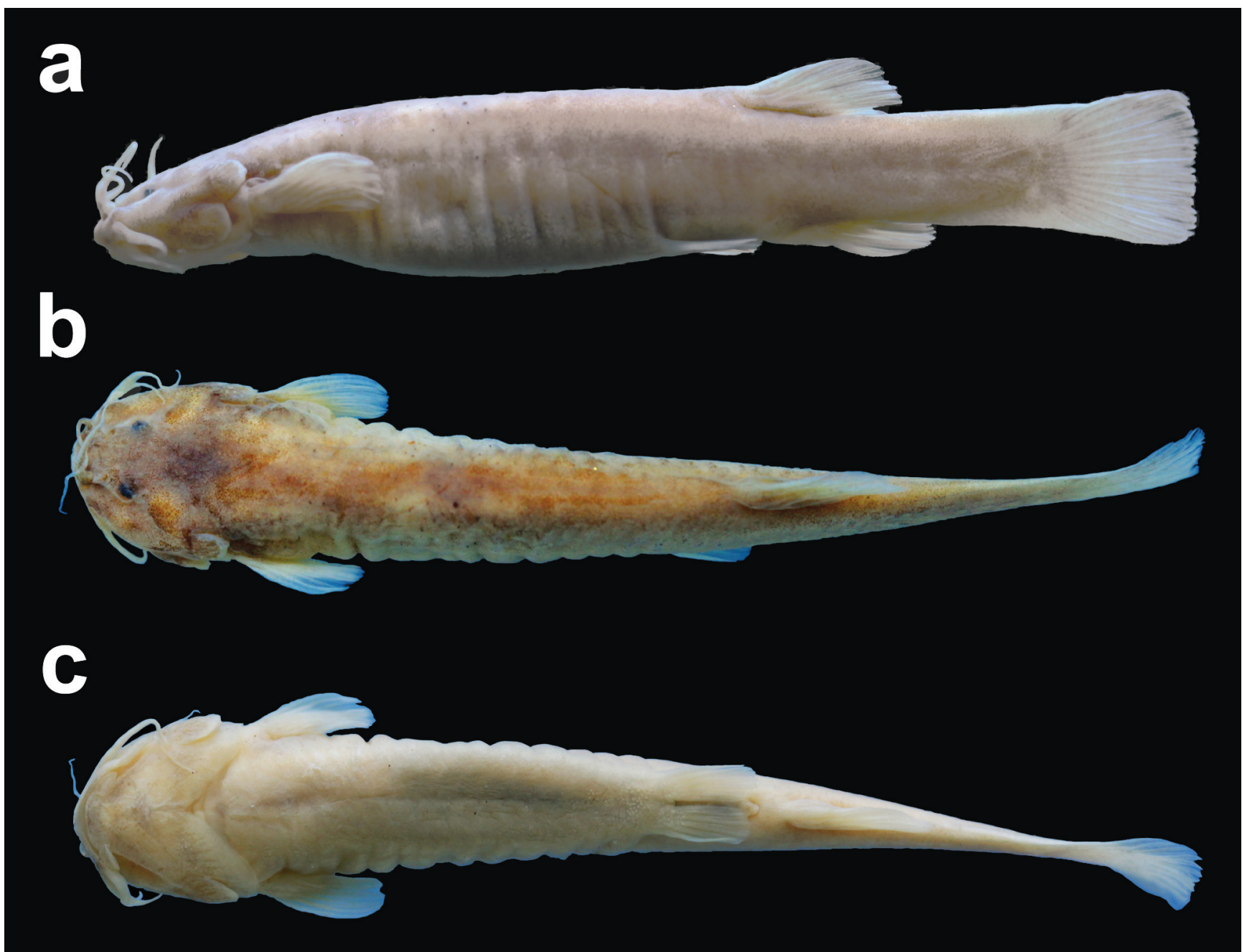

Fig. 1. Trichomycterus payaya, holotype, MNRJ 36665, $37.4 \mathrm{~mm}$ SL. Brazil, Bahia, Miguel Calmon, riacho Olhos d'água on road BA-131, tributary to rio Itapicuru-Mirim, between Miguel Calmon and Jacobina; a. lateral, b. dorsal, and c. ventral views.

The new species differs further from congeners of northeastern Brazilian drainages (T. bahianus, T. itacambirussu, T. jequitinhonhae, T. landinga, T. pradensis) by having a large opercular odontode patch with 16-19 odontodes (vs. small odontode patch with 8-13 odontodes). It differs further from $T$. bahianus, T. itacambirussu, and T. jequitinhonhae by having body coloration somewhat homogeneous, with minute spots distributed throughout ( $v S$. presence of rounded dark brown or gray spots sometimes arranged into series along body), from $T$. landing $a$ by having dorsal and ventral flanks similarly colored (vs. dorsal flank finely dotted and ventral flank with dark dots scarce), and from T.pradensis and T. itacambirussu by having six branched pectoral-fin rays ( $v s$. eight or nine). Trichomycterus payaya can be also distinguished from its congeners of the rio São Francisco drainage (T. brasiliensis, $T$. concolor, $T$. macrotrichopterus, $T$. novalimensis, $T$. reinhardti, $T$. rubiginosus, $T$. trefauti, $T$. variegatus) by having a narrower caudal peduncle (7.5-9.6\% vs. $10.5-13 \%$ of SL) and longer nasal barbel (14.2-15.9\% vs. 8.4-12.9\% of SL). See discussion for details on other distinguishing features.
Description. Morphometric and meristic data presented in Table 1. Body slim, trunk compressed, caudal peduncle laterally compressed. Dorsal profile of body gradually ascending from tip of snout to anterior portion of trunk, approximately straight from that point to base of dorsal fin, descending along dorsalfin base and straight on caudal peduncle until caudal fin. Ventral profile of head gently sloped. Ventral profile of body almost straight to shallowly convex.

Head rounded anteriorly in dorsal view, small, and slightly depressed. Eyes small, orbital margin not free; thin skin covering eye. Anterior nostril surrounded by fleshy, tubeshaped flap of integument. Posterior nostril surrounded anteriorly by raised fleshy flap and located slightly closer to anterior nostrils than to eye. Mouth subterminal; lower lip contoured by fleshy lobe medial to origin of rictal barbels; upper lip with fleshy fold limited to base of maxillary barbel. Nasal barbel originating on lateral portion of integumentary flap around anterior nostril; tip of barbel reaching opercular odontode patch. Maxillary barbel reaching pectoral-fin origin. Rictal barbel extending to interopercular odontode patch. 
Table 1. Morphometric data of holotype and paratypes of Trichomycterus payaya $(\mathrm{n}=15)$. The ranges include the holotype. $\mathrm{SD}=$ Standard deviation.

\begin{tabular}{lcccc}
\hline & Holotype & Range & Mean & SD \\
\hline Standard length (mm) & 37.4 & $29.2-37.4$ & 32.7 & - \\
Total length (mm) & 43.7 & $33.0-43.7$ & 38.0 & - \\
& Percents of Standard length & & \\
Body depth & 13.9 & $13.2-16.3$ & 14.4 & 1.12 \\
Body width & 10.7 & $10.0-14.0$ & 11.6 & 1.21 \\
Caudal peduncle depth & 9.1 & $7.5-10.2$ & 8.8 & 0.79 \\
Caudal peduncle length & 19.5 & $17.4-22.2$ & 19.7 & 1.18 \\
Predorsal length & 67.6 & $64.9-68.5$ & 66.9 & 1.11 \\
Preanal length & 69.3 & $66.8-71.8$ & 68.8 & 1.39 \\
Prepelvic length & 58.3 & $53.5-58.3$ & 54.8 & 1.81 \\
Dorsal-fin base length & 9.9 & $9.9-12.9$ & 11.4 & 0.85 \\
Anal-fin base length & 8.3 & $7.8-10.7$ & 9.2 & 0.88 \\
Dorsal-caudal length & 12.1 & $7.6-12.5$ & 10.3 & 1.53 \\
Nasal barbel length & 14.2 & $12.9-15.9$ & 14.8 & 0.93 \\
Maxillary barbel length & 16.6 & $13.8-19.1$ & 16.3 & 1.26 \\
Rictal barbel length & 13.1 & $12.6-15.8$ & 13.7 & 0.91 \\
Head length & 20.3 & $19.7-22.4$ & 21.1 & 0.81 \\
& 81.6 & $78.1-82.9$ & 80.8 & 1.44 \\
Head width & Percents of Head length & $37.0-43.1$ & 40.1 & 1.85 \\
Head depth & 25.0 & $25.0-29.3$ & 27.3 & 1.52 \\
Inteorbital distance & 15.8 & $11.9-15.8$ & 14.4 & 1.25 \\
Internarial distance & 21.4 & $21.1-27.3$ & 24.3 & 2.01 \\
Internarial width & 35.5 & $32.8-38.8$ & 35.8 & 1.74 \\
Snout length & 11.8 & $9.6-12.3$ & 11.2 & 0.84 \\
Orbital diameter & 36.8 & $35.6-40.9$ & 38.4 & 1.50 \\
Mouth width & \multicolumn{4}{c}{}
\end{tabular}

Autopalatine large, posteriorly expanded with wide lateral projection. Jaws subequal; premaxilla and dentary almost straight with two or rarely three rows of conical teeth. Premaxilla narrow, transversely elongated, meeting its counterpart medially. Maxilla well developed and curved. Branchial membranes thick, united to isthmus only anteriorly.

Mesethmoid long, thin, with anterior border slightly concave, premaxillary held underneath narrow anterior cornua through synchondral articulation. Lateral ethmoid projected laterally. Anterior cranial fontanel elliptical, bounded by frontals (Fig. 2). Epiphyseal bar incompletely sutured medially. Posterior cranial fontanel long and narrow, slightly expanded laterally along sutures between frontals and parietosupraoccipital. Lacrimal somewhat straight. Fronto-lachrymal tendon-bone long, rod-like, without lateral projection. Anterior portion of sphenotic-prootic-pterosphenoid projected laterally, bearing infraorbital sensory canal openings. Pterotic laterally projected. Posttemporo-supracleithrum short, in posterior corner of head, bearing postotic laterosensory branch. Vomer arrow-shaped, narrow, with long paired posterior processes. Parasphenoid with long posterior process, reaching middle of basioccipital-exoccipital (Fig. 3).

Anterior portion of Weberian complex fused to basioccipital-exoccipital. Suspensorium with robust hyomandibula, projected anteriorly as membranous outgrowth. Laminar projection of hyomandibula anteriorly sutured to quadrate only, not contacting metapterygoid. Metapterygoid short, laminar, almost rectangular, joined to quadrate via anterior cartilage block only. Quadrate elongate, with broad base and anterior laminar projection contacting both hyomandibula and metapterygoid. Quadrate and hyomandibula contacted also through their broad bases and cartilaginous joint. Short preopercle sutured to ventral margins of both quadrate and hyomandibula. Opercular patch of odontodes large and roundish. Opercle with 16-19* elongate odontodes, posterior ones longest. Interopercular patch of odontodes longer than deep, with short anterior process. Interopercle with $21-26^{*}$ odontodes arranged into two or three irregular rows (Fig. 4).

Hyoid arch with large ventral hypohyal, elongate anterior ceratohyal and somewhat triangular posterior ceratohyal with markedly concave posterior face and with articulatory surface for interopercle and ligamentous connection to suspensorium. Seven branchiostegal rays articulated with hyoid arch: three with anterior ceratohyal, one with interceratohyal cartilage between bones, and three with posterior ceratohyal. Brachiostegal rays 4-6, distally expanded and notched. Dorsal hypohyal and interhyal absent. Urohyal wide, bearing conspicuous foramen. Anterior head of urohyal expanded, lateral processes elongated, laminar, sharpened distally to pointed tip. Posterior process of urohyal moderately short and sharpened (Fig. 5).

Basibranchial 1 absent; basibranchial 2 and 3 with cartilaginous anterior and posterior tips, connected to each other, forming osseous rod. Anterior cartilaginous tip of basibranchial axis reaching close to hypobranchial 1; posterior osseous tips nearly in contact with contralateral hypobranchial 3. Cartilage between basibranchial 2 and 3 bordered laterally by cartilaginous head of hypobranchial 2 . Basibranchial 4 hexagonal and completely cartilaginous, bordered anteriorly by cartilaginous head of ceratobranchial 4 and posteriorly by cartilaginous head of ceratobranchial 5 . Hypobranchial 1 osseous, rod like, with cartilage on its proximal and distal tips. Hypobranchial 2 elongate, cartilaginous, almost trapezoid, with osseous anterodistal process. Hypobranchial 3 approximately trapezoidal, mostly cartilaginous and positioned close to its counterpart. Hypobranchial 4 absent. Five ceratobranchials, mostly ossified, extremities cartilaginous. First ceratobranchial short, supporting diminutive rakers. Second and third ceratobranchials each with shallow cavity along posterior margin and mesial laminar extension. Fourth ceratobranchial with diminutive concavity. Fifth ceratobranchial with short proximal tip, slightly expanded posteromedially to support lower pharyngeal tooth plate. Tooth plate with fine conical teeth arranged in two rows, with about seven teeth in mesial row. Five epibranchials, first three-rod like, short, ossified, except for cartilaginous extremities. Posterior margin of epibranchial 1 with elongate anterior process. Epibranchial 2 with vestigial process on its anterior margin. Epibranchial 3 with elongate posterior uncinate process. Epibranchial 4 broad, somewhat rectangular, without processes. Epibranchial 5 very small, completely cartilaginous, placed between posterior cartilaginous tips of epibranchial 4 and ceratobranchial 4. Pharyngobranchials 1 and 2 absent. Pharyngobranchial 3 elongate, ossified, rod-like, with 


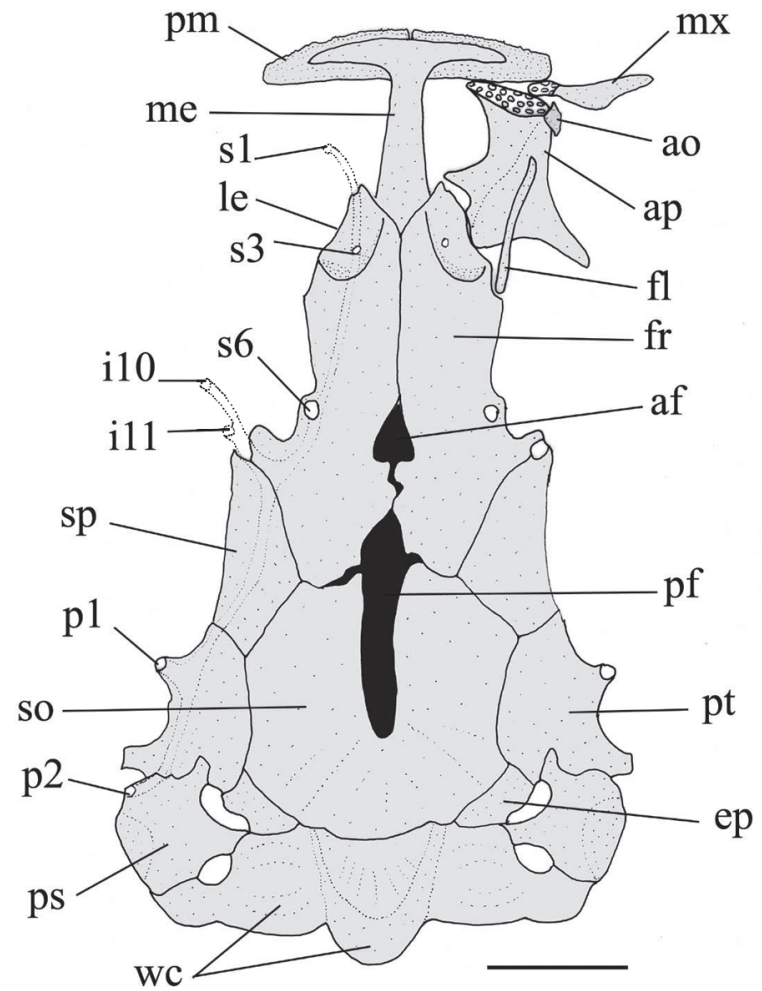

Fig. 2. Neurocranium and Weberian apparatus of Trichomycterus payaya, UFBA 5286, paratype, $31.4 \mathrm{~mm}$ SL. Dorsal view. Abbreviations: af, anterior fontanel; ao, lacrimal; ap, autopalatine; ep, epioccipital; fl, frontolacrimal tendon bone; fr, frontal; i10, i11, infraorbital sensory pores 10 to 11 ; le, lateral ethmoid; me, mesethmoid; mx, maxilla; pf, posterior fontanel; pm, premaxilla; ps, posttemporo supracleitrum; pt, pterotic; p1, p2, postotic sensory pores 1 to 2; so, parieto-supraoccipital; sp, sphenotic; s1, s3, s6, supraorbital sensory pores 1 to 6 ; wc, weberian complex and capsule. Scale bar $=1 \mathrm{~mm}$.

cartilaginous tips. Pharyngobranchial 4 ossified, suspending upper pharyngeal tooth plate. Teeth on upper pharyngeal tooth plate conical, arranged in two rows; eight teeth in main row (Fig. 6).

Cephalic sensory canals enclosed in bone, with some branches deeply embedded. Head sensory canals with simple tubes, each ending in single pore. All canals continuous and connected to each other. Supraorbital sensory canal running along frontal and nasal bones, giving off three paired pores: pore $\mathrm{s} 1$ placed between palatine and mesethmoid, pore $\mathrm{s} 3$ between anterior margin of frontal and vomer, and pore $\mathrm{s} 6$ on frontal, close to lateral border. Pores s1 and s3 placed between anterior margin of frontal and vomer. Pore s6 opening laterally on supraorbital sensory branch, not emerging from epiphyseal branch. Supraorbital canal joining infraorbital canal on anterior part of sphenotic. Infraorbital canal incomplete, running along head surface, giving off two branches, anterior one with pores i1 and i3, connected by single canal, both close to lacrimal,

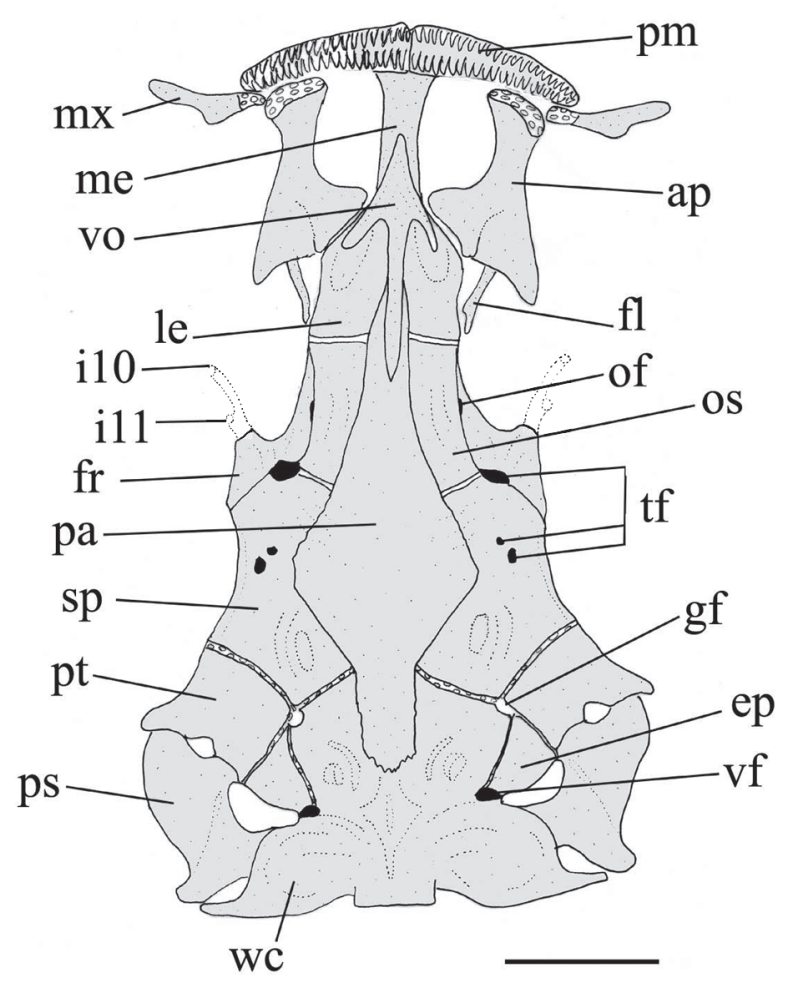

Fig. 3. Neurocranium and Weberian apparatus of Trichomycterus payaya, UFBA 5286, paratype, $31.4 \mathrm{~mm}$ SL. Ventral view. Abbreviations: ap, autopalatine; ep, epioccipital; $\mathrm{fl}$, fronto-lacrimal tendon bone; fr, frontal; gf, foramen for anterior branch of glossopharyngeal nerve; i10, i11, infraorbital sensory pores 10 to 11 ; le, lateral ethmoid; me, mesethmoid; $\mathrm{mx}$, maxilla; of, optic foramen; os, orbitosphenoid; pa, parasphenoid; pm, premaxilla; ps, posttemporosupracleitrum; pt, pterotic; sp, sphenotic; tf, foramina for trigeminofacial nerve branches; vf, foramen for vagus nerve; vo, vomer; wc, weberian complex and capsule. Scale bar $=1 \mathrm{~mm}$.

anteriorly to eye; posterior one with pores i10 and i11 connected through single canal, near sphenotic border, ventroposteriorly to eye. Postotic sensory canal extending from posterior limit of optic sensory canal to anterior limit of lateral line, with pore 1 opening on pterotic border. Preopercle-mandibular sensory canal absent. Otic sensory canal short, without pores. Lateral-line canal very short, with three pores. Pore 111 on postemporal-supracleithrum, pores 112 and 113 on lateral side of body posterior to opercle.

Dorsal-fin ii, 7, its margin somewhat rounded, with four procurrent rays. Basal dorsal-fin radials eight. Dorsal-fin base located between verticals through $20^{\text {th }}$ and $25^{\text {th }}$ vertebra $(\mathrm{n}=$ 3). Pectoral fin i,6. Some specimens with minute filamentous extension to tip of first unbranched pectoral-fin ray; others without such extension. Pelvic fin i,4, small with margin rounded, origin located at vertical through about $17-18^{\text {th }}$ vertebrae. Anal fin ii,5, with three procurrent rays. Anal-fin pterygiophores arranged as six thin, elongate proximal radials 


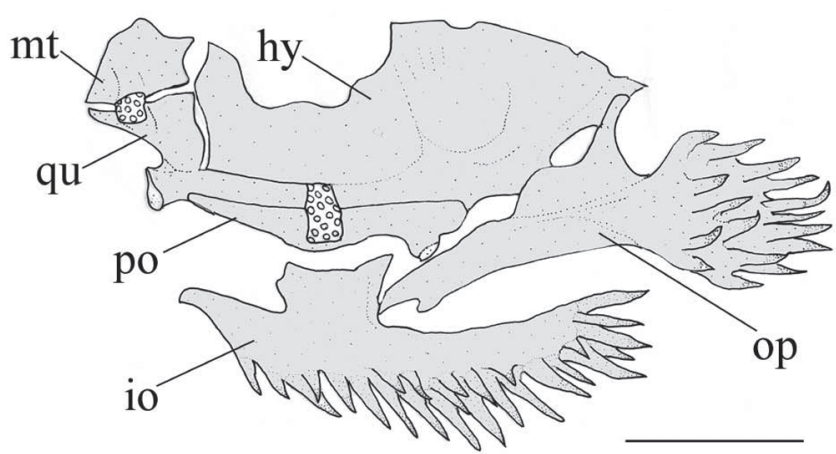

Fig. 4. Left suspensorium of Trichomycterus payaya, UFBA 5286, paratype, $31.4 \mathrm{~mm}$ SL. Lateral view. Abbreviations: hy, hyomandibula; io, interopercle; mt, metapterygoid; op, opercle; po, preopercle; qu, quadrate. Scale bar $=1.5 \mathrm{~mm}$.

and five very small, completely cartilaginous distal radials. Caudal fin truncated, $6+5$ principal rays $(\mathrm{n}=15)$; dorsal procurrent rays 12 ; ventral procurrent rays $10-12 *$. Precaudal vertebrae $12-13$. Total vertebral $36(n=3)$. Paired pleural ribs $5-6(n=3)$, becoming progressively thinner anteroposterioly. Sixth unpaired rib present only on right side in smallest c\&s specimen examined (UFBA 5286).

Color in alcohol. Body color pale brown to light gray, somewhat homogeneous, with minute dark chromatophores distributed throughout; ventralmost lateral portion clearer; ventral surface white. Dorsal surface of head with dark brown area at nape. Nasal barbel dark brown; maxillary barbel pigmented dorsally; rictal barbel light yellow. Dorsal and caudal fins with brown chromatophores along borders of rays; basal portion of dorsal-fin membrane pigmented similarly to body. Pectoral, pelvic and anal fins somewhat lighter, with dark chromatophores restricted to region near base of rays (Fig. 1).

Live coloration. Ground color light yellow to somewhat translucent. Some specimens mottled with pale brown spots. Head pale yellow with scattered grayish-brown chromatophores. Dorsal portion of head with dark central area, posterior to eyes. Ventral surfaces translucent. Fins almost hyaline (Fig. 7).

Distribution. Known from two tributaries of the rio Itapicurumirim, in the headwaters of the rio Itapicuru basin, northern Bahia State (Fig. 8).

Etymology. The specific name payaya honors the Payayá, an indigenous people who once inhabited the area south of the rio São Francisco, between the upper rio Itapicuru and rio Paraguassu valleys to the Recôncavo Baiano, in northern Bahia State (Dantas et al., 1992). The Payayá occupied the region called "Sertão da Jacobina" until the $18^{\text {th }}$ Century. Although the Payayá people are considered extinct for a long time, their descendents nowadays inhabit the region of the

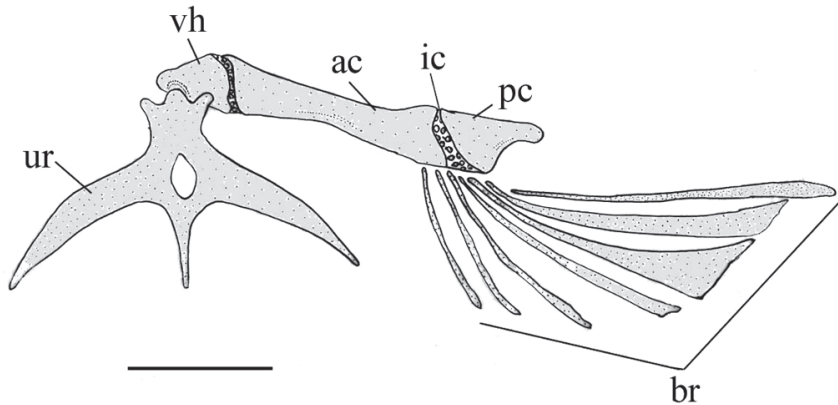

Fig. 5. Left hyoid arch of Trichomycterus payaya, UFBA 5286, paratype, $31.4 \mathrm{~mm} \mathrm{SL}$. Ventral view. Abbreviations: ac, anterior ceratohyal; br, branchiostegal rays; ic, interceratohyal cartilage; pc, posterior ceratohyal; vh, ventral hypohyal; ur, urohyal. Scale bar $=1 \mathrm{~mm}$.

Chapada Diamantina, in northern Bahia State (Dantas et al., 1992; Santos, 2008).

Habitat and ecology. Trichomycterus payaya was captured in two small streams ( 1 to $7 \mathrm{~m}$ wide and up to $1 \mathrm{~m}$ deep), characterized by somewhat turbid water and moderate current over sandy bottom with pebbles, relatively low altitude (505$547 \mathrm{~m}$ above sea level), and surrounding vegetation mainly composed of grasses (Fig. 9). The stomach contents of four specimens were analyzed ( 2 c\&s, UFBA 5284, young male, $24.1 \mathrm{~mm}$ SL; MBML 2560, young female, $30.1 \mathrm{~mm} \mathrm{SL}$; 2 in alcohol, UFBA 5286, young female, $31.1 \mathrm{~mm}$ SL, and UFBA 5284 , young male, $36.5 \mathrm{~mm} \mathrm{SL}$ ). Contents revealed the presence of Chironomidae larvae, Ephemeroptera nymphs, fragments of insects and organic matter. The new species was collected

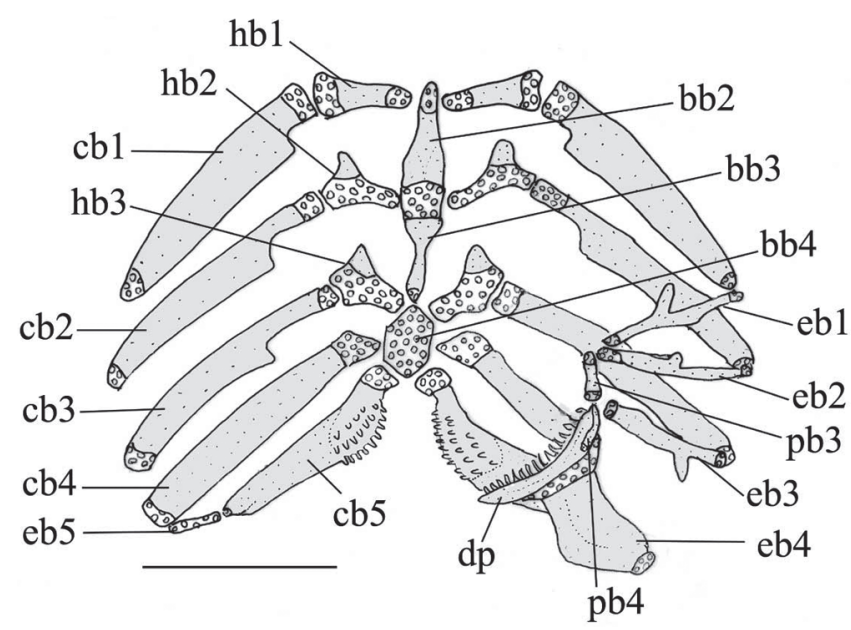

Fig. 6. Branchial skeleton of Trichomycterus payaya, MBML 2533, paratype, $31.1 \mathrm{~mm} \mathrm{SL}$. Dorsal view (right dorsal elements and gill rakers not shown). Abbreviations: bb2 to bb4, basibranchial 2 to 4 ; cb1 to cb5, ceratobranchials 1 to 5 ; dp, dentigerous plate; eb1 to eb5, epibranchials 1 to 5 ; hb1 to hb3, hypobranchials 1 to 3 ; pb3 to pb4, pharyngobranchials 3 and 4 . Scale bar $=1 \mathrm{~mm}$. 


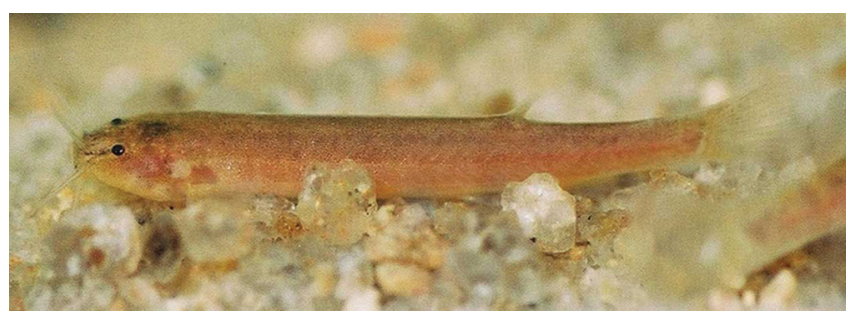

Fig. 7. Trichomycterus payaya, living specimens photographed in a field aquarium shortly after collection. Photo by O. T. Oyakawa.

syntopically with Astyanax cf. lacustris, A. aff. fasciatus, Characidium sp., Gymnotus cf. carapo, Hoplias malabaricus, Parotocinclus bahiensis, Piabina argentea, Pimelodella itapicuruensis, Poecilia reticulata, Rhamdia quelen, Serrapinnus heterodon, S. piaba, and Steindachnerina sp.

\section{Discussion}

The headwaters of the upper rio Itapicuru, where specimens of Trichomycterus payaya were caught, drain the northern portion of the Chapada Diamantina domain. Neighboring headwaters include those of the rio Paraguaçu to the south and lower stretches of the rio São Francisco to the north and west. A few trichomycterids have been recorded for northeastern Brazil, including four species endemic to headwaters of the rio Paraguaçu: Copionodon pecten, $C$. orthiocarinatus, Glaphyropoma rodriguesi, G. spinosum, and Ituglanis paraguassuensis (de Pinna, 1992; Campos-Paiva \& Costa, 2007; Santos \& Caramaschi, 2007; Bichuette et al., 2008) and two species from southern Bahia: Trichomycterus bahianus and T. pradensis (Costa, 1992; Sarmento-Soares et al., 2005). The six Trichomycterus species assigned to the rio São Francisco basin were described from its upper and middle stretches, in Minas Gerais State (Lütken, 1875; Eigenmann, 1918; Costa, 1992; Trajano \& de Pinna, 1996; Wosiacki, 2004). The only species reported from the Caatinga of the rio São Francisco valley, at northern Minas Gerais State, is Trichomycterus itacarambiensis (Trajano \& de Pinna, 1996; Rosa et al., 2003). Trichomycterus payaya is the first record for the genus in northern Bahia coastal rivers and the only known species inhabiting coastal rivers draining the Caatinga Biome of northeastern Brazil.

Trichomycteridae is a particularly diverse group, with more than 200 species, distributed in eight subfamilies: Copionodontinae, Trichogeninae, Vandeliinae, Stegophilinae, Tridentinae, Glanapteryginae, Sarcoglanidinae, and Trichomycterinae (de Pinna, 1998). Seven of these subfamilies, with the exception of the Trichomycterinae, are considered monophyletics. The Copionodontinae and Trichogeninae are sister groups and together represent the sister group to all other trichomycterids ("Clade C" sensu de Pinna, 1998; Datovo \& Bockmann, 2010). Trichomycterus payaya shares all synapomorphies for "Clade C" trichomycterids (sensu de Pinna, 1992, 1998; Bockmann et al., 2004): sphenotic, prootic and pterosphenotic fused, incomplete infraorbital branch of laterosensory canal, Weberian capsule with small lateral opening, interhyal absent, five or fewer pelvic-fin rays, anterior cranial fontanel partially or completely closed, dorsal caudal-fin plate with six or fewer rays, ventral caudal-fin plate with eight or fewer rays, dorsal caudal-fin lobe with five or fewer branched rays, ventral caudal-fin lobe with six or fewer rays. On the other hand, the new species lacks those synapomorphies that support the monophyletic Copionodontinae and Trichogeninae clade (de Pinna, 1998). Additional features for "Clade C", present also in T. payaya, include protactor operculi muscle present and levator operculi muscle fibers posterodorsally directed (Datovo \& Bockmann, 2010).

A monophyletic assemblage composed of the subfamilies Tridentinae, Stegophilinae, Vandeliinae, Sarcoglanidinae, and Glanapteryginae (called TSVSG clade, sensu Costa \& Bockmann, 1993), was defined on the basis of four synapomorphies: posterior elongated process of parasphenoid absent, metapterygoid reduced or absent, interopercular patch of odontodes reduced in length with 15 or fewer odontodes, and six or less epipleurals ribs (Costa \& Bockmann, 1993). Scleronema and Ituglanis were recognized as more closely related to the clade TSVSG (de Pinna, 1998), but still remain in the unresolved Trichomycterinae subfamily. Trichomycterus payaya has the lateral process of the urohyal sharp and elongated, a condition very similar to those found in derived trichomycterids such as Trichomycterus hasemani, T. johnsoni, Scleronema, Ituglanis and also the TSVSG clade (as in Costa \& Bockmann, 1993; de Pinna, 1998; Wosiacki, 2002). However, the interopercular patch of odontodes is well developed and longer than deep in T. payaya, a condition distinctive from that found in those derived trichomycterids wherein the interopercle is nearly as long as deep and there is a tendency towards bone reduction (de Pinna, 1998). The sharpening of the urohyal lateral process and the reduction of the interopercular patch of odontodes seem to have intermediate states across Scleronema, Ituglanis, and Trichomycterus lineages (Datovo \& Bockmann, 2010). The new Trichomycterus species also shares with both Ituglanis and the TSVSG clade a reduced number of epipleural ribs, 56 (vs. 9 in Scleronema operculatum). In spite of having those features, T. payaya is not considered a member of the clade composed of Scleronema, Ituglanis, and TSVSG assemblage because it does not have other derived features of this clade, such as interopercular patch of odontodes reduced, as stated above, and three or fewer abdominal vertebrae (de Pinna, 1998).

The non-monophyletic nature of the Trichomycterinae is well known (Baskin, 1973; de Pinna, 1989; de Pinna, 1998) and this subfamily has been gradually eroded by the exclusion of species and groups of species more closely related to other subfamilies (de Pinna, 1998). Although basically diagnosed by the lack of specializations of the other subfamilies, the Trichomycterinae was tentatively diagnosed by Arratia (1990). Trichomycterus payaya possesses the diagnostic characters of the Trichomycterinae (sensu Arratia, 1990), such as 
basioccipital with well-developed anterior process, enarthrodial articulation between the preopercle and the opercle, vomer with long posterior process, and pronounced notch on posteroventral margin of ceratobranchial 3. Arratia's (1990) proposal for the monophyly of the Trichomycterinae was weakened by de Pinna (1998), on the basis of the absence of the cited characters in Trichomycterus hasemani (Schaefer \& Fernandez, 2009). In spite of the controversies regarding the recognition of the Trichomycterinae, the new species is herein considered a member of this subfamily due to overall similarity to Trichomycterus and by virtue of not sharing those characters that diagnose any of the other trichomycterid subfamilies.

The Trichomycterinae is currently composed by Bullockia, Eremophilus, Hatcheria, Ituglanis, Rhizosomichthys, Scleronema, Silvinichthys, and Trichomycterus (Arratia, 1990; Wosiacki \& de Pinna, 2008b). Within this subfamily, T. payaya lacks the synapomorphies for Bullockia, Eremophilus, Hatcheria, Rhizosomichthys, and Scleronema (Arratia, 1990) and Silvinichthys (Arratia, 1998; Fernandez \& de Pinna, 2005). In comparison to Ituglanis, Trichomycterus payaya lacks the three synapomorphies postulated by Costa \& Bockmann (1993) for that genus: (1) supraoccipital fontanel reduced to a small round orifice ( $v s$. wide posterior cranial fontanel between frontals and supraoccipital in T. payaya), (2) palatine with a deep medial concavity and anterior extremity of the sphenotic directed anteriorly ( $v s$. palatine with a medial shallow concavity in $T$. payaya), and (3) anterior portion of sphenotic directed anteriorly ( $v s$. anterior portion of sphenotic directed laterally, together with posterior border of frontal in T. payaya). We observed that in Ituglanis the infraorbital sensory canal emerges directly from the sphenotic instead of emerging between the frontal and the sphenotic as in T. payaya. In spite of this, T. payaya shares some external morphological features with Ituglanis along the Atlantic coastal rivers (e.g., Ituglanis cahyensis, I. paraguassuensis, I. parahybae, and I. proops), such as a depressed head, low number (usually two) of tooth rows on premaxilla and dentary, shallow abdominal cavity, and dorsal fin posteriorly placed. The proportional distance from the dorsal-fin origin to base of middle caudalfin rays (DFC) in predorsal length (PDL) was employed to check the position of dorsal fin among Trichomycterus and Ituglanis species. We observed a more anterior position of the dorsal fin in Trichomycterus, with the ratio PDL/DFC 1.41.9. On the other hand, a more posterior position of the dorsal fin was observed in Ituglanis, with the ratio PDL/DFC 2.2-2.8. In T. payaya the ratio PDL/DFC has intermediate values, 1.92.2. Also, the paired supraorbital pore s6 opening laterally on supraorbital sensory branch and not emerging from an

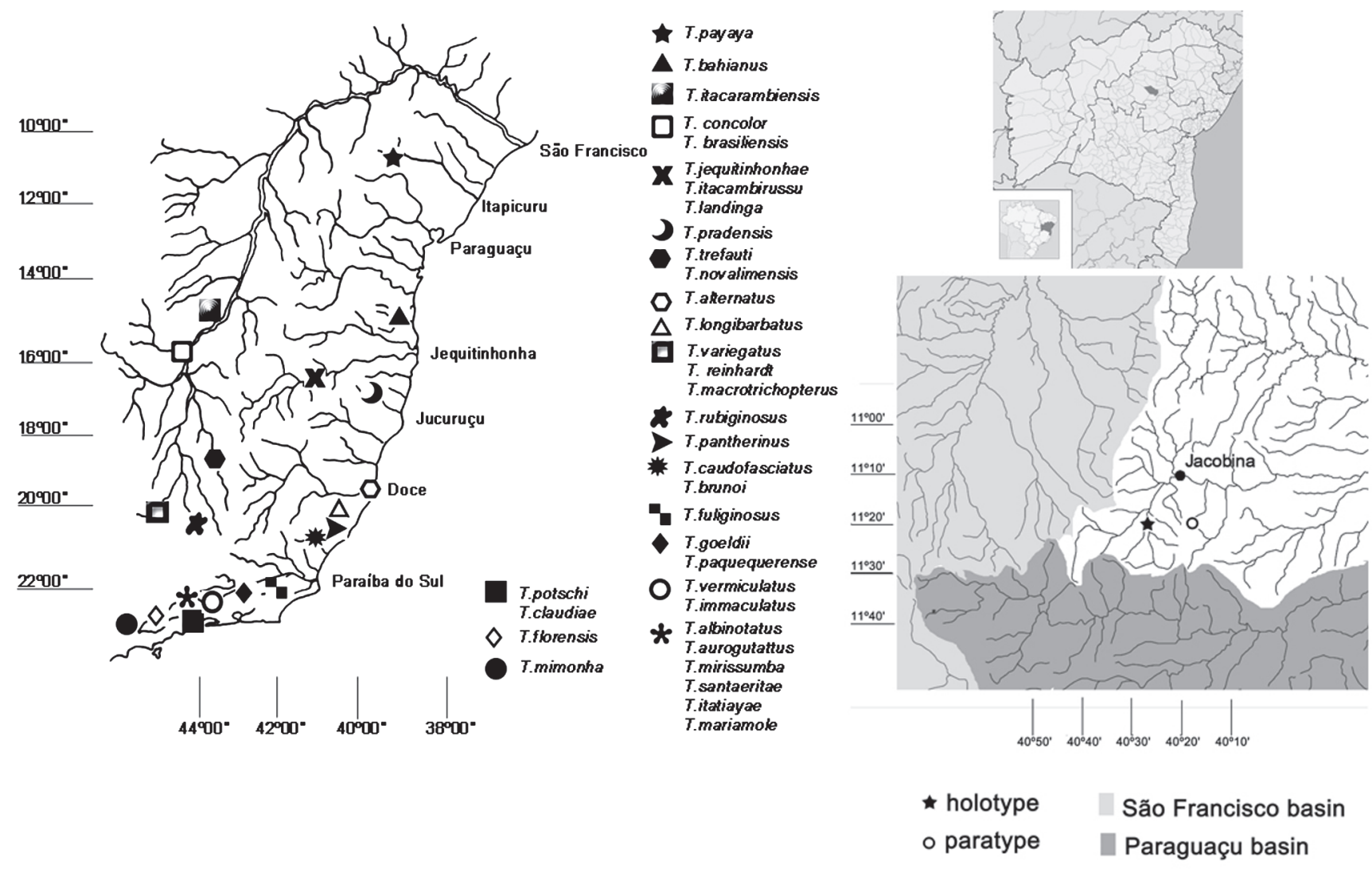

Fig. 8. Eastern Brazilian drainages between rio São Francisco and rio Paraíba do Sul, illustrating the distribution of the Trichomycterus species in the area, location of Miguel Calmon Municipality in Bahia State and in Brazil, and details of collecting localities of Trichomycterus payaya in the rio Itapicuru drainage, and neighbor river basins. 
epiphyseal branch in T. payaya resembles the condition observed for Ituglanis cahyensis and I. parahybae (illustrated in fig. 2 of Sarmento-Soares et al., 2006). Paired s6 pores separated from each other on the interorbital region, near the cranium border, is also observed in Ituglanis paraguassuensis (fig. 2c). In Trichomycterus species along Southeastern and Eastern hydrographic regions (T. giganteus, $T$. nigricans, $T$. paquequerensis, $T$. caudofasciatus, and T.pantherinus), the supraorbital pore $s 6$ is placed at the interorbital space, emerging from an epiphyseal branch, even in the specimens with a single symphyseal pore s6. The position of s6 pores in $T$. payaya is unique among cited Trichomycterus species.

Although determining the relationships of T. payaya is a complex task, the species is herein tentatively included in the genus Trichomycterus, due to the absence of the three derived characters for Ituglanis and to the lack of the synapomorphies of other trichomycterid clades. Trichomycterus comprises the majority of species in Trichomycterinae and is currently undiagnosable by synapomorphies (Wosiacki \& de Pinna, 2008a). Recent molecular evidence suggests that Ituglanis is a monophyletic group sister to all Trichomycterus, with the exception of $T$. hasemani (Sato, 2007). Thus, further phylogenetic studies are necessary to check the position of T. payaya within Trichomycterus and the subfamily.

Comparative material. Brazil. Ituglanis cahyensis: Bahia: MNRJ 28405, 2 c\&s, paratypes (41.3- 48.6 mm SL), Prado, rio Palmares on road Guarany-Corumbau; MNRJ 28406, 1 paratype (28.6 mm SL), Prado, rio Palmares on road Guarany-Corumbau, near Palmares. I. paraguassuensis: Bahia: MBML 2599, 2 (40.1-40.6 mm SL); MBML 2600, 1 c\&s (38.0 mm SL); UFBA 4362, 7 (28.7-41.6 mm SL), Wagner, rio Cachoeirinha, tributary of rio Utinga. I. parahybae: Rio de Janeiro: FMNH 58576, 1, holotype (I, R), São João da Barra, rio Paraíba do Sul; MNRJ 782, 2 (40.0-40.9 mm SL), rio Imbú; MNRJ 15413, 4, 1 c\&s (32.7-44.5 mm SL); MZUSP 79810, 1 (41.9 mm SL), Silva Jardim, tributary of rio São João in Gaviões. I. proops: São Paulo: MNRJ 13597, 9, 1 c\&s, topotypes (56.3-

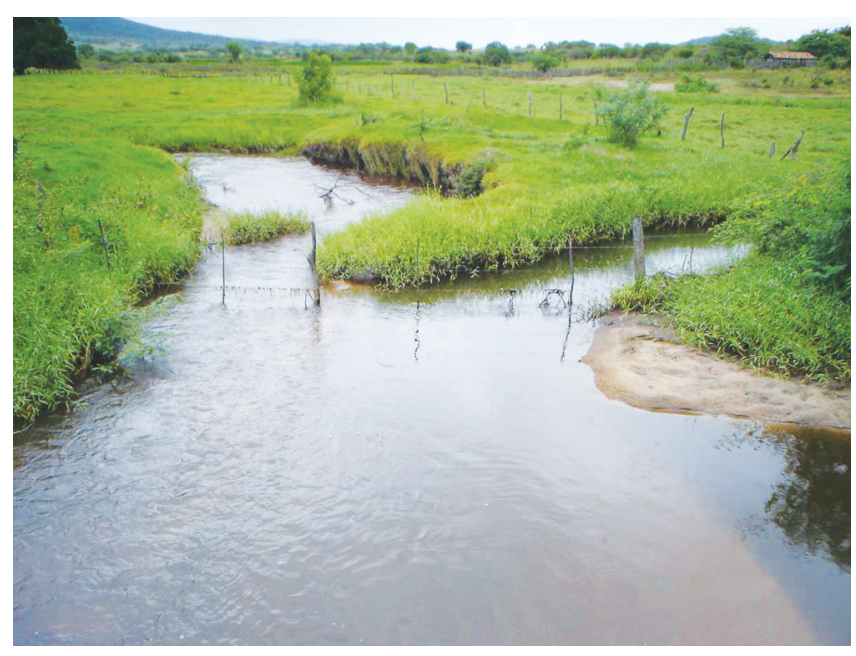

Fig. 9. Type locality of Trichomycterus payaya, Brazil, Bahia, Miguel Calmon, riacho Olhos d'água, rio Itapicuru basin.
$68.9 \mathrm{~mm}$ SL), Iporanga, rio Betari, rio Ribeira basin. Scleronema operculatum: Rio Grande do Sul: FMNH 58080, holotype (I, R), Cacequy. Trichomycterus albinotatus: Rio de Janeiro: MNRJ 21182, 33 (39.0- $50.0 \mathrm{~mm} \mathrm{SL}$ ), Nova Friburgo, locality of João Brande, rio Grande headwaters. T. alternatus: Espírito Santo: MBML 2602, 1 c\&s (44.0 mm SL), Santa Teresa, rio Santa Maria do Rio Doce, on Cachoeira do Rúdio. Minas Gerais: MNRJ 17167, 1 (45.3 mm SL), MNRJ 17168, 1 (70.1 mm SL), córrego Curral Velho, tributary of rio Gualaxo do Sul, contributor to the right margin of rio do Carmo. T. bahianus: Bahia: MBML 1579, 2 (57.6- 60.9 mm SL), Wenceslau Guimarães, córrego da Piaba, Reserva Biológica Wenceslau Guimarães; MBML 1580 (48.3- 64.7 mm SL), Boa Nova, tributary of rio Urubu, near Valentim Village; MBML 1585, 10 (51.2- 110.0 $\mathrm{mm}$ SL), Boa Nova, riacho Timorante, near Valentim Village; MBML 1587, 2 (45.8- 51.9 mm SL), Boa Nova, tributary of rio Valentim; MBML 2142, 2 c\&s (52.5- 57.5 mm SL), Camacan, rio Panelinha near Biscó Village. T. brasiliensis: Minas Gerais: MBML 1597, 2 (83.3- $115.1 \mathrm{~mm}$ SL), Ouro Preto, small river on Lavras Novas; ZMUC P-30163, 1 syntype, (R); ZMUC P-30164, 1 syntype, (R); ZMUC P-30165, 1 syntype, (R), rio das Velhas. T. caipora: MNRJ 31924, 1 paratype (78.0 mm SL), Conceição de Macabu, rio Macabu upstream the confluence of rio Carocango and rio Macabu rio Macabu, Lagoa Feia drainage. T. caudofasciatus: Espírito Santo: MBML 2402, 2 (28.3- 42.1 mm SL), Dores do Rio Preto, riacho Azul; MBML 2410, 2 (49.8-62.2 mm SL), Divino São Lourenço, riacho Veadinho. Minas Gerais: MCP 35030, 1, paratype, (I), Alto Caparão, Rio Caparaó, rio Itabapoana basin. Trichomycterus florense: Rio de Janeiro: MNRJ 14405, 32 (31.0- 50.0 mm SL), riacho Caxumba, rio Paquequer drainage. São Paulo: MNRJ 23991, 1 (74.4 mm SL), Taubaté, ribeirão do Machado. T. goeldii: Rio de Janeiro: MNRJ 14020, 38 (45.0- $60.0 \mathrm{~mm} \mathrm{SL),} \mathrm{rio} \mathrm{Paquequer;}$ BMNH 1896.7.4.7-8, 1, syntype, (I), Colônia Alpina. T. itacambirussu: Bahia: MBML 1504, 1 (84.1 mm SL), Jacinto, Areinha stream, on road Jacinto to Salto da Divisa. T. itatiayae: Rio de Janeiro: MNRJ 20049, 1 (72.1 mm SL), Itatiaia, Parque Nacional do Itatiaia. T. longibarbatus: Espírito Santo: MBML 620, 4 (42.9$66.4 \mathrm{~mm}$ SL), Santa Teresa, rio Lombardia, Nova Lombardia; MBML 799, 1 (23.3 mm SL), Santa Teresa, rio Saltinho; MBML 801, 3 (60106,4 mm SL), Santa Teresa, rio Saltinho, on Boeirão; MBML 1344, 19 (37- $75.4 \mathrm{~mm} \mathrm{SL}$ ), Santa Teresa, rio Lombardia, on Nova Lombardia; MBML 2031, 2 (56.8- 58.7 mm SL), Santa Teresa, rio Timbuí, on Estação Biológica Santa Lúcia; MBML 2562, 1 (43.1 mm SL), Santa Teresa, rio Lombardia. T. jequitinhonhae: Minas Gerais: MBML 1495, 9 (42.6- 63.9), MBML 2116, 1 (45.8 mm SL), MBML 2561, 1 c\&s (49.4 mm SL), Jacinto, tributary of córrego Areia, near Jaguarão. T. nigricans: Santa Catarina: MNHN B251, holotype, (R), rio Itapocu. T. pantherinus: Espírito Santo: MBML 462, 1 (55.4 mm SL), Santa Maria de Jetibá, rio Santa Maria da Vitória; MBML 502, 3 (101.6- 107.7 mm SL), Santa Maria de Jetibá, rio Santa Maria da Vitória, on Alto Santa Maria; MBML 1318, 2 (81.7-86.9 mm SL), Santa Maria de Jetibá, rio Santa Maria da Vitória, on Cachoeira do Pastor; MBML 1643, 1 (40.1 mm SL), Santa Leopoldina, rio da Prata; MBML 2251, 5 (77.2- 110.3 mm SL), Santa Maria de Jetibá, rio Taquarinha da Penha; MBML 2261, 5 (41-111 mm SL), Santa Maria de Jetibá, rio Santa Maria da Vitória on Balneário Ilha Berger. T. paquequerense: Rio de Janeiro: MNRJ 12841, 4 (32.2- 60.0 mm SL), córrego Quebra Frasco, rio Paquequer drainage, upstream from road Teresópolis-Petrópolis; MNRJ 12842 , 3 (26.4- 35.6 mm SL), córrego Jacó, rio Piabanha drainage, upstream from road Teresópolis to Petrópolis; MNRJ 14349, 1 (50.0 mm SL), Teresópolis, rio Paquequer, near Parque Nacional da Serra dos Órgãos. T. pradensis: Espírito Santo: MNRJ 17251, 1 (41.0 mm 
SL), córrego Dezoito, rio Itaúnas basin; MNRJ 17263, 1 (43.6 mm SL), MNRJ 17265, 1 (45.6 mm SL), MNRJ 21429, 1 (70.6 mm SL), rio Itauninhas, rio Itaúnas basin. Bahia: MBML 1474, 4 (30.9$34.6 \mathrm{~mm}$ SL), Itabela, rio São Gonçalo on road Itabela to Guaratinga; MBML 1480, 10 (45.1- 50.8 mm SL), Guaratinga, córrego Itu on road Guaratinga to Buranhém; MBML 1520, 9 (36.3- 57.5 mm SL), Santa Cruz de Cabrália, rio Santo Antônio near Barrolândia. MNRJ 28491, 1 paratype (35.1 mm SL), Medeiros Neto, córrego Água Fria. T. reinhardti: Minas Gerais: MNRJ 17059, 1 (44.5 mm SL), córrego Debaixo da Serra, tributary on the right margin of córrego Água Limpa, tributary on the right margin of córrego das Painas, tributary on the left margin of córrego Beijinho; MNRJ 21416, 2 (50.6-68.7 $\mathrm{mm} \mathrm{SL}$ ), river crossing road MG-030, tributary of rio Itabira, between Engenheiro Correia and Miguel Burnier.

\section{Acknowledgements}

We wish to thank the Setor de Ictiologia of the Museu Nacional and the Setor de Zoologia of the Museu de Biologia Professor Mello Leitão. Thanks to Aléssio Datovo, Mark Allen, Mélyne Hautecoeur, and Peter Rask Moller for providing images and/or radiographs in association with the All Catfish Species Inventory website image bank. Specimens of the new species were gathered through fieldwork funded by the All Catfish Species Inventory (NSF DEB-0315963), during Expeditions to the rios Paraguaçu and Itapicuru, in July 2005. We thank Osvaldo T. Oyakawa, Marcos P. Geraldes, Priscila C. A. Cardoso, and Perimar Moura for their help in the field. Rafael Burger photographed the holotype. Permission for collecting specimens was granted by IBAMA. The paper benefited from the comments and suggestions of Mark H. Sabaj-Peres, Wolmar B. Wosiacki and anonymous reviewers.

\section{Literature Cited}

Arratia, G. 1990. Development and diversity of the suspensorium of the trichomycterids and comparison with loricarioids (Teleostei, Siluriformes). Journal of Morphology, 205: 193218.

Arratia, G. 1998. Silvinichthys, a new genus of trichomycterid catfishes from the Argentinian Andes, with redescription of Trichomycterus nigricans. Ichthyological Exploration of Freshwaters, 9: 347-370.

Arratia, G. 2003. Catfish head skeleton. An overview. Pp. 20-46. In: Arratia, G., B. G. Kapoor, M. Chardon, R. Diogo (Eds.). Catfishes. Science Publishers, Enfield, USA.

Arratia, G. \& L. Huaquin. 1995. Morphology of the lateral line system and of the skin of diplomystid and certain primitive loricarioid catfishes and systematic and ecological considerations. Bonner Zoologische Monographien, 36: 1-110.

Barbosa, M. A. \& W. J. E. M. Costa, 2003. Trichomycterus potschi (Siluriformes: Loricarioidei): a new trichomycterid catfish from coastal streams of southeastern Brazil. Ichthyological Explorations of Freshwaters, 14: 281-287.

Barbosa, M. A. \& W. J. E. M. Costa. 2008. Description of a new species of catfish from the upper rio Paraíba do Sul basin, south-eastern Brazil (Teleostei: Siluriformes: Trichomycteridae) and re-description of Trichomycterus itatiayae. Aqua, International Journal of Ichthyology, 14: 175-186.
Barbosa, M. A. \& W. J. E. M. Costa. 2010. Seven new species of the catfish genus Trichomycterus (Teleostei: Siluriformes: Trichomycteridae) from southeastern Brazil and redescription of T. brasiliensis. Ichthyological Explorations of Freshwaters, 21: 97-122.

Baskin, J. N. 1973. Structure and relationships of the Trichomycteridae. Unpublished Ph.D. Dissertation. City University of New York, 389p.

Bichuette, M. E., M. C. C. de Pinna \& E. Trajano. 2008. A new species of Glaphyropoma: the first subterranean copionodontine catfish and the first occurrence of opercular odontodes in the subfamily (Siluriformes: Trichomycteridae). Neotropical Ichthyology, 6: 301-306.

Bockmann, F. A., L. Casatti \& M. C. C. de Pinna. 2004. A new species of trichomycterid catfish from the Rio Paranapanema basin, southeastern Brazil (Teleostei: Siluriformes), with comments on the phylogeny of the family. Ichthyological Exploration of Freshwaters, 15: 225-242.

Bockmann, F. A., \& I. Sazima. 2004. Trichomycterus maracaya, a new catfish from the upper rio Paraná, southeastern Brazil (Siluriformes: Trichomycteridae), with notes on the $T$. brasiliensis species-complex. Neotropical Ichthyology, 2: 6174.

Campos-Paiva, R. M. \& W. J. R. M. Costa. 2007. Ituglanis paraguassuensis sp. n. (Teleostei: Siluriformes: Trichomycteridae): a new catfish from the rio Paraguaçu, northeastern Brazil. Zootaxa, 1471: 53-59.

Costa, W. J. E. M. 1992. Description de huit nouvelles espèces du genre Trichomycterus (Siluriformes: Trichomycteridae), du Brésil oriental. Revue Française d'Aquariologie et Herpetologie, 18: 101-110.

Costa, W. J. E. M. \& F. A. Bockmann. 1993. Un nouveau genre néotropical de la famille des Trichomycteridae (Siluriformes: Loricarioidei). Revue Française d'Aquariologie et Herpetologie, 20: 43-46.

Dantas, B. G., J. A. L. Sampaio \& M. R. G. Carvalho. 1992. Os povos indígenas no nordeste brasileiro: um esboço histórico. Pp. 431-456. In: Cunha, M. C. (Org.). 1992. História dos Índios no Brasil. 2 Ed. Companhia das Letras, São Paulo, Brasil.

Datovo, A. \& F. A. Bockmann. 2010. Dorsolateral head muscles of the catfish families Nematogenyidae and Trichomycteridae (Siluriformes: Loricarioidei): comparative anatomy and phylogenetic analysis. Neotropical Ichthyology, 8: 193-246.

Eigenmann, C. H. 1918. The Pygidiidae, a subfamily of South American catfishes. Memoirs of the Carnegie Museum, 7: 259398.

Fernández, L. \& G. Miranda. 2007. A catfish of the genus Trichomycterus from a thermal stream in southern South America (Teleostei, Siluriformes, Trichomycteridae), with comments on relationships within the genus. Journal of Fish Biology, 71: 1303-1316.

Fernández, L. \& M. C. C. de Pinna. 2005. Phreatic catfish of the genus Silvinichthys from southern South America (Teleostei, Siluriformes, Trichomycteridae). Copeia, 2005: 100-108.

Lima, S. M. Q. \& W. J. E. M. Costa 2004. Trichomycterus giganteus (Siluriformes: Loricarioidea: Trichomycteridae): a new catfish from the Rio Guandu basin, southeastern Brazil. Zootaxa, 761: 1-6.

Lima, S. M. Q., H. Lazzarotto \& W. J. E. M. Costa 2008. A new species of Trichomycterus (Siluriformes: Trichomycteridae) from Lagoa Feia drainage, southeastern Brazil. Neotropical Ichthyology, 6: 315-322. 
Lütken, C. H. 1875. Velhas-Flodens Fiske. Et Bidrag til Brasiliens Ichthyologi. Kongelige Danske Videnskabernes Selskabs Skriften, 12: 122-252.

de Pinna, M. C. C. 1989. A new sarcoglanidine catfish, phylogeny of its subfamily, and an appraisal of the phyletic status of the Trichomycterinae (Teleostei, Trichomycteridae). American Museum Novitates, 2950: 1-39.

de Pinna, M. C. C. 1992. A new subfamily of Trichomycteridae (Teleostei, Siluriformes), lower loricarioid relationships and a discussion on the impact of additional taxa for phylogenetic analysis. Zoological Journal of the Linnean Society, 106: 175229.

de Pinna, M. C. C. 1998. Phylogenetic relationships of Neotropical Siluriformes (Teleostei: Ostariophysi); historical overview and synthesis of hypothesis. Pp. 279- 330. In: Malabarba, L. R., R. E. Reis, R. P. Vari, Z. M. Lucena, \& C. A. S. Lucena (Eds.). Phylogeny and Classification of Neotropical Fishes. Edipucrs, Porto Alegre, Brazil, 603p.

de Pinna, M. C. C., \& W. Wosiacki. 2003. Trichomycteridae. Pp. 270-290. In: Reis R. E., S. O. Kullander \& C. J. Ferraris, Jr. (Eds.). Check list of the freshwater fishes of South and Central America. Edipucrs, Porto Alegre, Brazil, 729p.

Rosa, R.S., N. A. Menezes, H. A. Britski, W. J. E. M. Costa \& F. Groth. 2003. Diversidade, padrões de distribuição e conservação dos peixes da caatinga. Pp. 135- 180. In: Leal, I. R., Tabarelli, M. \& Silva, J. M. C. (Eds.). Ecologia e Conservação da Caatinga. Editora Universitária da Universidade Federal de Pernambuco, Recife, Brasil.

Santos, A. C. A. \& E. P. Caramaschi. 2007. Composition and Seasonal Variation of the Ichthyofauna from Upper Rio Paraguaçu (Chapada Diamantina, Bahia, Brazil). Brazilian Archives of Biology and Technology, 50: 663-672.

Santos, S. N. A. 2008. Os payayá e suas relações de contato no Sertão das Jacobinas (1651-1706). Anais do II Encontro Internacional de História Colonial. A experiênica colonial no Novo Mundo (séculos XVI a XVIII). Simpósio 2. História e Resistência Indígena no Brasil Colonial. Mneme - Revista de Humanidades da Universidade Federal do Rio Grande do Norte, Edição Especial 9: 1-17.

Sarmento-Soares, L. M., R. F. Martins-Pinheiro, A. T. Aranda \& C. C. Chamon. 2006. Ituglanis cahyensis, a new catfish from Bahia, Brazil (Siluriformes: Trichomycteridae). Neotropical Ichthyology, 4: 309-318.

Sato, L. R. 2007. Estudo das relações filogenéticas de Trichomycteridae (Teleostei, Siluriformes) com base em evidências cromossômicas e moleculares. Unpublished Ph.D. Dissertation, Universidade Estadual Paulista, Botucatu, 87p.

Schaefer, S. A. \& L. Fernández. 2009. Redescription of the Pez Graso, Rhizosomichthys totae (Trichomycteridae), of Lago de Tota, Colombia, and Aspects of Cranial Osteology Revealed by Microtomography. Copeia 2009: 510-522.

Taylor, W. R. \& G. Van Dyke. 1985. Revised procedures for staining and clearing small fishes and other vertebrates for bone and cartilage study. Cybium, 9: 107-119.

Tchernavin, V. V. 1944. A revision of some Trichomycterinae based on material preserved in the British Museum (Natural History). Proceedings of the Zoological Society of London, 114: 234275.

Trajano, E. \& M. C. C. de Pinna. 1996. A new cave species of Trichomycterus from eastern Brazil (Siluriformes, Trichomycteridae). Revue Française d'Aquariologie et Herpetologie, 23: 85-90.
Trajano, E., S. Secutti \& M. E. Bichuette. 2009. Natural history and population data of fishes in caves of the Serra do Ramalho karst area, Middle São Francisco basin, northeastern Brazil. Biota Neotropica 9: 129-133.

Triques, M. L. \& V. Vono 2004. Three new species of Trichomycterus (Teleostei: Siluriformes: Trichomycteridae) from the rio Jequitinhonha basin, Minas Gerais, Brazil. Ichthyological Exploration of Freshwaters, 15: 161-172.

Wosiacki, W. B. 2002. Estudo das relações filogenéticas de Trichomycterinae (Teleostei, Siluriformes, Trichomycteridae) com uma proposta de classificação. Unpublished Ph.D. Dissertation, Universidade de São Paulo, São Paulo, 324 p.

Wosiacki, W. B. 2004. New species of the catfish genus Trichomycterus (Siluriformes, Trichomycteridae) from the headwaters of the rio São Francisco basin, Brazil. Zootaxa, 592: $1-12$.

Wosiacki, W. B. 2005. A new species of Trichomycterus (Siluriformes: Trichomycteridae) from south Brazil and redescription of T. iheringi (Eigenmann). Zootaxa, 1040: 49-64.

Wosiacki, W. B. \& M. C. C. de Pinna. 2008a. Trichomycterus igobi, a new catfish species from the rio Iguaçu drainage: the largest head in Trichomycteridae (Siluriformes: Trichomycteridae). Neotropical Ichthyology, 6: 17-23.

Wosiacki, W. B. \& M. C. C. de Pinna. 2008b. A New Species of the Neotropical Catfish Genus Trichomycterus (Siluriformes: Trichomycteridae) Representing a New Body Shape for the Family. Copeia, 2008: 273-278.

Accepted January 14, 2011

Published June 30, 2011 